\title{
Post-colonial histories, common people, and commercial frameworks
}

The New Order can be construed as a neo-imperialist or neocolonialist regime (Anderson 1990; Sen 2003). Particularly in the period immediately after the resignation of President Soeharto, discussions began to emerge in the world of film which addressed concepts of post-colonialism in cinema. This chapter examines a variety of post-colonial discourses and discourse practices in film after the eclipse of the New Order. The guiding theme is Fairclough's premise (1995:52) that all ongoing changes in society and culture are expressed in the media's diverse and conflicting shifts in discursive practices. I analyse the way in which, after the stepping down of President Soeharto, new post-colonial discourses and imaginations of society were reflected in film discourse practices. I explore the emergence of alternative genres and try to pinpoint the continuations in particular modes of engagement, the dominant representations of topics which are part of the central discourses in a society, and the practice of framing films, which continued to survive during Reformasi. As argued by Fairclough (1995:65), the discursive practices of an unsettled society are on average variable and unstable, while the discursive practices of a conservative and established society are unitary and conventional. Using this argument, I will examine variations and continuities in representations of Indonesian history and society during the traumatic yet exciting times of Reform.

COUNTER-HISTORY: CHANGES AND CONTINUITIES IN POST-SOEHARTO MODES OF ENGAGEMENT

In the euphoric atmosphere of Reform that prevailed after the resignation of President Soeharto, attempts were enthusiastically 
made in all kinds of fields to adapt to changes in the socio-political conditions of the Indonesian nation or to set them in motion. Some debates addressed the problem of New Order historiography and the need to 'set history straight' (meluruskan sejarah). ${ }^{1}$ Hence dominant representations of New Order film history also came under fire. In addition to questioning the highlights in film history, several debates concentrated on New Order propaganda historical films. The contents and compulsory screening of the film Penumpasan pengkhianatan $G 30 S / P K I$ in particular were targeted.

The excitement of Reform and the concomitant sudden freedom of expression generated new developments in discursive practices which inevitably involved the contents and mediation of films. Different film-makers, both professional and amateur, began to produce films in order to present new versions of history and society. In a short time, there was a rise in the production of documentaries. A large number of the new documentaries told alternative or counter-histories to those which unfolded under the New Order. Generally speaking, these documentaries tended to focus on the victims of Soeharto rule. Those who had suffered were given a platform to tell their stories about the atrocities committed under the New Order. Several non-governmental organizations, both foreign and domestic, aided in producing and funding these documentaries. The film Kameng gampoeng nyang keunong geulawa (Aryo Danusiri, 1999), for example, was supported by the Indonesian Institute for the Study of Human Rights and Advocacy Elsham, and his film Penyair negeri Linge (The poet of Linge homeland, 2000) by the Ford Foundation. The film Perempuan di wilayah konflik (Women in conflict zones, Gadis Arivia, 2002) was produced by the Yayasan Jurnal Perempuan (Women's Journal Foundation); Lahir di Aceh (Born in Aceh, Ariani Djalal, 2003) was produced by the Tifa Foundation and Offstream Production; Pena pena patah (Broken pens, Sarjev Faozan, 2002) was produced by the Coalition of NGO's on Human Rights in Aceh; and Kado buat rakyat Indonesia (A present for the Indonesian people, Daniel Indra Kusuma, 2003) was supported by the Centre for Democracy and Social Justice and the Indonesian Centre for Reform and Social Emancipation.

Besides documentaries, a few fiction films based on true stories of human rights violations were also produced. For example, the docu-drama Puisi tak terkuburkan (English title: A Poet, Garin

1 For more on the debates on the need to 'straighten history', see Schulte Nordholt 2004:11-2. Another comprehensive study on coming to grips with New Order historiography during reform is Zurbuchen 2005 . 
Nugroho, 1999) was about Ibrahim Kadir, a traditional poet from the village of Takengon in Aceh, who in 1965 was accused of being a communist activist. He was imprisoned for twenty-two days and witnessed a variety of cruel executions. Marsinah (Slamet Rahardjo, 2002) was about the murder of a woman factory worker by the authorities in East Java in May 1993. Kutunggu di sudut Semanggi (I'll be waiting at the corner of Semanggi, Lukmantoro, 2004) was based on the Semanggi tragedy of November 1998. Many counter-history film and documentary productions circulated at independent-film screenings and film festivals, both in Indonesia and abroad. Some even reached Indonesian cinemas, but hardly any of these films were ever screened on Indonesian television, enabling them to attract the same attention and reach enjoyed by the New Order history films in the past.

The new documentaries and their screening at film festivals and other venues gradually set in motion a shift in the meaning of the genre. From being a propaganda instrument under the New Order, documentary was transformed into a genre which, in the words of documentary film-maker Lexy Rambadeta, gave a 'voice to the voiceless'. Nevertheless, the notion that the documentary genre almost invariably contained propaganda lingered on for quite some time. The legacy of the New Order associated with this genre was apparent in the film-makers's choice to produce either a documentary or a fiction film after the collapse of the New Order regime. If their objective was to make a claim that the contents of the film represented facts based on reality, some film-makers would, in fact, prefer to make a fiction film rather than a documentary. To cite one example, in 2000 the Universitas Muhammadiyah Malang (UMM, Muhammadiyah University in Malang) wanted to produce a film which would give an account of the propagation of Islam in Indonesia. This film was to be based on authentic historical evidence obtained from sources collected by the Muhammadiyah. The principal of the university, Mahadjir Effendi, said they had decided to make a fiction film instead of a documentary 'to avoid the practices of manipulation, as had been done in the historical documentary G30S/PKI'. In his opinion a fiction film was not only easier to digest, it was also more 'objective'. ${ }^{2}$

Although there was a discernible rise in documentaries which countered New Order propaganda and historiography, particularly in the first years of Reform many new productions employed structures, styles, and formulas which did not deviate greatly from New Order propaganda and history films. This practice will be

2 'UMM buat film penyebaran Islam di Indonesia', Media Indonesia, 18-7-2000. 
explored in the next section. Bill Nichols postulates that the use of certain styles and modes of production in documentaries defines concepts of historical representation. He argues that such modes of documentary production as 'expository', 'observational', 'interactive', and 'reflexive' function in the same fashion as genres, in that they are ways of characterizing films by their likeness to rather than their differences from one another. But instead of co-existing as different types of imaginary worlds (science fiction, westerns, melodrama), modes represent different concepts of historical representation. Nichols claims that different modes may co-exist at any moment in time and can be transposed across different periods and national cinemas. The creation of a new mode is the result of challenge and contestation elicited by a previous mode (Nichols 1991:22-3). As Nichols links modes of documentary production to different concepts of historical representation, this presupposes that the appearance of new modes also challenges previous models of historical representation. Nichols' argument about modes of production applies equally to modes of engagement. However, in early post-Soeharto documentaries specific New Order modes of engagement were repeated, even though the purpose of the films was to edit and re-edit collective memory. In the following section I will analyse this process, bearing in mind that the reproduction of New Order audio-visual styles, structures, and narratives in postSoeharto documentary productions may also simply relate to the widespread practice of jiplak-menjiplak (the replication, imitation, or blatant copying) of film formulas.

The post-Soeharto documentary Mass grave (2001, Lexy Rambadeta) addresses an aspect of Indonesian history which was passed over in silence under New Order rule. The film is about the exhumation in Central Java in 2001 of a mass grave. The grave contained the remains of alleged PKI members who were massacred in the mountains of Wonosobo, sometime in 1965-1966. In its opening scenes, Mass grave instantly recalls the visualization of New Order documentaries and the film Penumpasan pengkhianatan G30S/PKI. The similarities are particularly striking, though, in the composition of the last fifteen minutes of the film. The closing scenes of G30S/PKI are devoted to the retrieval of the bodies of the slain generals from the dry well of Lubang Buaya. Soon after the start of the scene, the image of the tops of the trees clustered around the well are shown, shot from a low angle. Then from a top angle the camera zooms in on the well from which the decomposing bodies of the generals are taken out one by one. Thereupon, the camera moves back filming the bystanders. The position of the bystanders, among them the actor playing the role of Major General Soeharto, 
was a detailed reconstruction from the historical archive material of the event. On screen a text appears alerting the audience that the voice which they are about to hear is the authentic recorded live speech of Soeharto obtained from archive material. At the same time the speech begins to be broadcast in the background, the soundtrack of 'Gugur bunga di taman bakti' (which was composed during the presidency of Soekarno to pay respect to national heroes who had fallen in the struggle for Independence) begins to play. At that point, the original colour image of G30S/PKI is replaced by black-and-white archive material. In the minutes that follow the film continues by cross-cutting shots of the re-enacted drama, copying the archive material of the incident in detail, with real footage of the occasion in black and white.

The film ends by showing archive material of the state funeral of the generals and the authentic live speech delivered by General Nasution in 1965, in which he recalls the sacred tasks of the Armed Forces as defenders of freedom, the people, and the highest authorities of the nation. He asserts his belief that the slain generals are national heroes who paid the ultimate price and that the living members of the Armed Forces should continue to uphold these values. In both the dramatized version, which is filmed in colour, and in the historical black-and-white footage, some shots of photo and film cameras are included in order to emphasize that these cameras captured and recorded the event to which the viewers bear witness. ${ }^{3}$ By comprehensive use of the cross-cutting of fictional film with historical audio and visual archive material in the last fifteen minutes of the documentary, G30S/PKI emphasized it was not merely a representation of the past, but a representation of the facts: 'the true story'.

The documentary Mass grave reproduced the structure and some of the visual aspects of Hapsak and the last fifteen minutes of G30S/PKI. However, the human remains exhumed could not have been more different: not those of the generals at Lubang Buaya, but those of the people killed in massacres in 1965 in Central Java. Just as in the film G30S/PKI, after its opening scene, which shows a map of the location, Mass grave begins with the depiction of the tops of the trees encircling the mass grave in Wonosobo. Then the camera zooms in on the exhumation of the skulls and bones of people who perished in the bloody aftermath of the 1965 coup. After this opening sequence, the documentary introduces black-and-white archive material. This time it is not the set-up of the scene itself, but the

3 I would like to thank Patricia Spyer and P.M. Laksono, who brought this use of cameras in the film to my attention. 
insertion of old stock footage and newsreel images which remind the viewer of New Order documentaries. The same material was televised each year under the New Order before the Hapsak ceremony commenced to illustrate the story of the historical events which occurred in 1965. The visual structure and style of the opening scenes of Mass grave revived and repeated images which easily could have been part of the collective memories of Indonesians who lived through the New Order. I am thinking especially of the image of the retrieval of the decomposing bodies of the murdered generals from a dry well at the end of G30S/PKI. This image was now replaced by the dry bones of the victims from the mass grave in Wonosobo, brought to the surface one by one. Importantly, in Mass grave old stock footage and newsreel images, familiar to many, were used again, but this time provided with a new narration exposing the atrocities committed at the founding of the New Order.

The second example of a post-Soeharto documentary which reproduces particular emblems of the film G30S/PKI and the Hapsak ceremony is Tino Saroengallo's 1998 documentary Student movement in Indonesia. It depicts demonstrations and rallies and the ensuing violent clashes between student activists and the Indonesian army in Jakarta in 1998. The documentary recounts the incidents at the Trisakti University and at the Semanggi flyover in which students were shot dead by Indonesian military. In this documentary an important audio motif of G30S/PKI and the Hapsak ceremony, the song 'Gugur bunga di taman bakti', appears and is commented on. In G30S/PKI, 'Gugur bunga' is used as a theme song at the end of the film. In the last fifteen minutes the soundtrack of the song is heard as though from a great distance as the bodies of the generals are retrieved. The song can be heard more loudly in the background to the live speeches of Soeharto and Nasution. 'Gugur bunga' was a leitmotif during the Hapsak ceremony, in which it featured over and over again. Often the song was played exactly at the moment when the president either headed for the children's orchestra or when he was standing in front of it. The song also often featured in the background to the newsreel and stock footage broadcast before the Hapsak ceremony commenced. In Student movement, students sang the song to commemorate the Trisakti incident. In the documentary, a voice-over comments that the students and the army were singing the same songs of bravery and nationalism.

The reproduction of certain audio and visual structures or emblems from the film G30S/PKI and the Hapsak ceremony can be seen as quotations of important New Order electronic monuments which tell new histories. Ella Shohat and Robert Stam (1994:353) 
suggest that 'The same filmic images and sounds provoke distinct reverberations in different communities'. To paraphrase them, in post-Soeharto Indonesian communities, some filmic images and sounds evoked specific reverberations. Quotations of audio and visual aspects of the film G30S/PKI and the Hapsak media event might have acted as an instant trigger to the subtexts of these themes, which relate to conceptions of heroism and nationalism. Although this was not necessarily the intention of the directors of the films, the examples demonstrate a juxtaposition of old images and new narrations, and new images and old narrations. ${ }^{4}$ The altered use of emblems which were part of memory sites of the New Order now abstracted from their source functioned as a device which re-structured national history and public memory. At screenings of Mass grave in Jakarta in 2002 and 2003, audiences commented that the film instantly brought to mind images of the decomposing bodies of the generals in the epic G30S/PKI. In their theory of media events, Dayan and Katz (1992:211) postulate that the collective memory in a society is edited and re-edited by quoting from earlier events. These Indonesian documentaries, in which specific monumental images and sounds were used in a different context, are examples of such a process. In the case of Mass grave, the same mode of visual representation was employed to reverse the authorized story and tell quite another tale: that of the victims of the New Order. ${ }^{5}$ In the documentary Student movement, the melody 'Gugur bunga di taman bakti' was quoted to usher in new national heroes: the Trisakti students who were killed by the Indonesian army.

The emphasis on victims and newly created heroes in two very disparate documentaries can be used to illustrate preoccupations with certain modes of representation in a majority of documentaries which were produced after the end of Soeharto rule. In the first few years of Reform, many new and 'counter-propaganda' films and documentaries were used to provide a forum for victims and shape new heroes to displace the old, hackneyed ones. Apart from the documentary Student movement, which used the song 'Gugur bunga'

4 In April 2007, when I asked Lexy Rambadeta whether he had G30S/PKI in mind when producing Mass Grave, he answered that the film had not crossed his mind for a minute. He had looked at more 'universal' modes of documentary production, like those used by the Australian television network ABC. The editor of Mass grave, Laurensius 'Goeng' Wijayanto, whom I met in December 2005, however, remarked that the film G30S/PKI was in his thoughts all the time while he was working on Mass grave. This could not have directly influenced the content or style of the film, though, since Goeng had simply followed Lexy's script and instructions.

5 Besides digging up the dead of New Order rule, Mass grave contested the narratives of evil communists versus good Islam. The documentary shows a group of angry Muslim men who violently try to prevent the reburial of victims of 1965 in the village's graveyard. 
to define the heroes of the Reformasi, the reproduction of the conventional narrative trait of heroism in New Order propaganda and historical films was significant. In December 2003, the organizing committee of the Indonesian Documentary Film Festival (FFD) in Yogyakarta allowed me to watch all fifty or so films which were to participate in the FFD competition that year. Watching these films, it struck me that a substantial part of the documentaries followed a New Order or gelora pembangunan-dictated style. As mentioned in Chapter 3, this kind of documentary begins with a map and a voiceover which, assuming a particular documentary narration pitch, gives precise information about the setting or location of the film. In the meantime, some sort of unrelated entertaining 'cheery' music score can be heard playing in the background. Most of the films I saw which began in this fashion could be fast-forwarded to just a few minutes before the end. There indisputably the hero of the story would emerge. Depending on the subject of the documentary, all the main characters - the housewife, the person collecting the garbage, or the man cutting trees for a living - were positioned as heroes, fulfilling the ordinary day-to-day 'heroic' deeds of common people. The overt gelora pembangunan type of documentaries stood no chance of selection in the competition. Instead, the festival committee chose films which were either shot in a 'Discovery' or 'National Geographic' channel style, or entries which exhibited more creative modes of documentary production. In 2004 and 2005, most documentaries entering the FFD competition had discarded the styles and contents of the New Order. By this time they were not much different to those featuring in international documentary film festivals worldwide. ${ }^{6}$

The fact that post-Soeharto documentaries continued to depict heroes has to be seen as a legacy of the New Order, in the sense that this narrative trait conveyed a partial extension of its textual conventions. It put forward a particular understanding of the modes used in the representation of documentaries which were formed under Soeharto rule. ${ }^{7}$ The parallel trend in the new documentary

6 For a database of contemporary Indonesian documentaries, see http://www.in-docs.com/ index.cfm. In-docs was founded in 2002 by Yayasan Masyarakat Mandiri Film Indonesia (YMMFI, Society of Indonesian Films), the founder and organizer of the Jakarta International Film Festival. Through In-docs, YMMFI promotes and encourages the production and development of documentary films by Indonesians. In-docs organizes a series of such programmes as discussions about documentaries, film screenings, and workshops for documentary production. In-docs is supported by the Ford Foundation, Hivos, and the Open Society Institute. For more on FFD, see their website: http:/ /www.festivalfilmdokumenter.org (accessed 23-1-2012).

7 For more on the structure of documentaries in relation to (generic) text conventions and parallels with other texts, as well as the use of certain styles in relation to institutional discourse, see Nichols 1991:18-23. 
productions, which now highlighted the victims of the regime, was part of the same discourse; only the point of view was turned around 180 degrees. $^{8}$ Nevertheless, there was also an important innovation in both the post-Soeharto documentaries on victims of New Order rule and those featuring new heroes. Their chosen focus was the common people: victims, students, housewives, or people collecting garbage. These documentaries revealed a shift from the 'voice of authority' to the 'voice of the voiceless' and they substituted tokoh for ordinary people. The emphasis on victims and newly found heroism in the early post-Soeharto documentaries initially showed that dominant discourses and narrative structures of New Order historiography were being reproduced. ${ }^{9}$

\section{POST-COLONIAL HISTORIES AND IDENTITIES: FILM ISLAMI}

Representations of Islam in Indonesian audio-visual media and Muslim participation in the Indonesian mediascape both increased significantly after the resignation of President Soeharto. The rise of Islamic film production companies and the empowerment of Islamic film communities required that new practices of Islamic self-representation be found. One group of young Islamic filmmakers in particular shaped new discourses on the position and representations of Islam in Indonesian and transnational audiovisual media. This new film movement explicitly referred to the post-colonial discourses deriving from Third Cinema theories. Moreover, their discourses indicated affiliations with communities worldwide.

Film and Islam were not easily united. Under the New Order, ulama (Muslim religious scholars) discussed the issue of film officially for the first time in 1983. In the same year, the film Sunan

8 For more about the emphasis on victims in audio-visual and other media after the resignation of Soeharto, see Wiwik Sushartami's research on the victimization of women in postSoeharto Indonesian media (forthcoming).

9 A different narration and representation of heroes and history was depicted in the film Gie (Riri Riza, 2005). Gie is based on the life and diaries of the Chinese-Indonesian student activist Soe Hok Gie, who opposed the rule of President Soekarno in the 1960s. Gie gradually turned into a cult figure following his death mountain climbing in 1969. His diaries were banned during New Order rule, but they were read and popular among dissidents. Scholar of Indonesian cinema Intan Paramaditha, in her article 'Contesting Indonesian nationalism and masculinity in cinema', shows the way in which in Riza's production, Soe Hok Gie is portrayed as an unconventional hero. She compares representations of nationalism and gender in the films Penumpasan pengkhianatan G30S/PKI and Gie and analyses the ways in which Gie redefines established, New Order imaginations and conceptions of nationhood and gender relations (Paramaditha 2007). 
Kalijaga (Sofyan Sharna) was produced. The film was based on the legend of Sunan Kalijaga, the first of the nine holy men who are believed to have disseminated the teachings of Islam in Java. In conjunction with the production of Sunan Kalijaga, a dialogue about film was organized between ulama from the Majelis Ulama Indonesia (MUI, Indonesian Council of Muslim Scholars) and film journalists. In newspapers it was said that most ulama believed it was unfitting to watch a film in a cinema, which was associated with indecent films and such improper behaviour as secretly kissing in the dark on a date (Bintang 1983; Jasin 1985). The aim of the dialogue was to explore to what extent film could be used as a form of Islamic preaching or dakwah (Islamic religious intensification activities),${ }^{10}$ and to find a way to combine the traditional mediation of oral preaching with the visual aspects of film. As some subjects may not be visualized in Islam, questions were raised about how religious teachings should be presented, and in what way certain specific religious principles could be represented in filmic symbols. However, most of the discussion concentrated on the film Titian serambut dibelah tujuh (English title: The narrow bridge, Chaerul Umam 1982), which was screened before the discussion in order to give the ulama an idea of what an Islamic film could be like. ${ }^{11}$

Approximately a year and a half after the initial formal discussion the first 'official' Indonesian Islamic mission film was produced. The fiction film with the title Sembilan wali (Nine saints, Djun Saptohadi, 1985) was based on various legends and folk-tales about the wali sanga which circulated in Indonesia. Following closely in the footsteps of Sembilan wali came another 'nine-saints film'. Once again this film, which bore the title Sunan Kalijaga E् Syeh Sitijenar (Sofyan Sharna, 1985), was about Sunan Kalijaga and his dealings with a renegade. The premiere of this film was watched by 250 ulama, who had gathered in Jakarta to attend the third national MUI meeting from 20 to 23 July 1985 . Although in the past many ulama had believed that watching films was haram (proscribed), this time those who were interviewed were generally approving. Nevertheless, they did not miss the opportunity to stress that particularly films which contained any slightly sexual scenes, such as nudity or unmarried men and women socializing together, were still prohibited. Perhaps because of the lack of titillating scenes, the film Sunan Kalijaga $\mathcal{E}^{\mathcal{O}}$ Syeh Sitijenar proved not to be particularly enthralling: many ulama fell asleep while watching it. When their opinion about

10 On the rise and context of dakwah in Indonesia, see Schulte Nordholt 2008:165-76.

11 'Ulama dan pers diskusikan kemampuan film sebagai medium syi'ar Islam', Berita Minggu EF Film, 14/20-8-1983. 
the film was asked, most of them could not comment because they had missed part or nearly all of it (Jasin 1985).

From 1989, discussions about the connection between film and Islam began to find their way into newspapers and magazines. The link between the two was also the subject of a number of conferences and gatherings. In these discussions various questions were addressed, such as: How should the production of 'entertaining' dakwah films be tackled? How could these be made to function as an alternative to oral preaching traditions? Was it possible to find a formula for a film with religious themes which would be acceptable to all parties? What role could be assumed by ulama or other religious authority figures in the production of films? There was a tacit agreement that the involvement of religious authorities was essential to pre-empt errors which could easily ignite the spark of protest. Should they merely act as consultants with the task of ensuring that everything to do with religion in that particular film was represented 'the right way'? Or should their involvement be more extensive? Should ulama also invent or propose ideas for films, indeed even become actors themselves, in order to attract an Islamic audience? ${ }^{12}$ Apart from these questions, most of which addressed the content of Islamic films, the bulk of the discussions about film and Islam was motivated by the perceived need for the production of Islamic films in modern Indonesia. ${ }^{13}$

Between 1994 and 1996, Islamic intellectuals stressed that in the present era of information and globalization it was extremely important to set up some resistance to the influx of films from overseas. They were convinced these films promoted nothing but secularism, sex, and violence (Arief 1996). If the Indonesian community were to produce Islamic films, Indonesians, of whom the majority were adherents of Islam, would be offered a lifeline by which to hold onto their own culture. Indonesian films did not escape criticism. Quite apart from 'hot' film productions, various films which the general public called 'Islamic mission films' were also frowned upon. Islamic scholars were concerned that broader audiences might become confused and believe that Indonesian horror and mystery films were actually dakwah films. Viewers indeed thought these types of film contained elements of religious

12 'KH Abdurrahman Arroisi; Agar dapat dijadikan sarana dakwah sulit mencari kriteria film bertema keagamaan', Harian Terbit, 1-9-1990; 'Sinetron atau film berthema agama hendaknya libatkan pakar agama', Angkatan Bersenjata, 20-11-1993; Cahyono 1989; Mahmud, Nashir and Agus Suryanto 1990.

13 'Pesantren jangan jauhi dunia kesenian dan film', Angkatan Bersenjata, 14-7-1993; Mahmud, Nashir and Agus Suryanto 1990. 
propagation because of the frequent deus ex machina role accorded Islamic figures. These were generally religious teachers or other Islamic symbols, which were introduced to restore order at the end of such films. In addition to horror films, other films which ulama considered to depict controversial scenes were also perceived by its audiences as Islamic mission films. Among them were several films which featured the famous actor and dangdut (popular music) star Rhoma Irama. General audiences were quick to interpret these as promoting Islam, because both in and outside the film world Rhoma Irama presented himself as a pious Muslim who brought faith to the people. The Islamic scholars thought otherwise, saying that Irama's films tended to feature too many 'hot scenes' to deserve the epithet of dakwah films. ${ }^{14}$

Alongside discussions about the need for more Islamic films there was a call for the establishment of Islamic film production companies. In 1996, Islamic organizations such as the mass organization Muhammadiyah took steps to found production houses furnished with all the equipment needed for film production. ${ }^{15}$ The zeal to establish Muslim film production companies was due to the victory of religious organizations in a political argument with the government. In May 1996, the government had issued a draft for new legislation on broadcasting which, among other regulations, prohibited the founding of private broadcasting organizations based on religious principles. After a vigorous discussion, fierce protests, and tough negotiations, the religious organizations won their case. On 18 June 1996, the incumbent Minister of Information, Hartono, announced that religious groups would be allowed to found their own broadcasting organizations. This victory gave a strong incentive to go ahead with the setting up of Islamic film production companies. ${ }^{16}$

As well as the plans and efforts to found production companies, strenuous attempts were made to empower young Muslims in audio-visual media. In 1993, at a seminar in Cirebon about the role

14 For example, the film Satria bergitar (The knight with a guitar, Nurhadie Irawan, 1983) shows scantily dressed females. There is also a scene set in the bedroom featuring the antagonist and his spouse. Even though the couple just talks, it was deemed inappropriate to have a scene set in a bedroom.

15 'Film bernuansa Islam tidak mendidik', Media Indonesia, 13-7-1996.

16 'Lima organisasi agama menolak pasal 9 RUU siaran', Harian Ekonomi Neraca, 22-51996; 'Kelompok keagamaan boleh bersiaran', Harian Terbit, 19-6-1996; 'Menpen; Kelompok keagamaan boleh dirikan lembaga penyiaran', Angkatan Bersenjata, 18-6-1996; Haryanto, Wijanta, and Tjiauw 1996; 'Lima lembaga keagamaan beri masukan RUU penyiaran', Angkatan Bersenjata, 22-5-1996; 'Menpen; Kelompok keagamaan boleh dirikan lembaga penyiaran', Kompas, 18-6-1996. 
of pesantren (Islamic boarding schools) in the era of industrialization, film-maker Erros Djarot stated that pesantren possessed great potential in helping to shape an Islamic art and film industry. He argued that santri (Islamic scholars) should not keep themselves aloof from the world of art and cinema. Instead of feeling downhearted watching non-Islamic films, santri should produce films themselves. ${ }^{17}$ In 1997, generated by the fear of a tidal wave of films from overseas and the annoyance aroused by incorrect, stereotypical representations of Islam in Indonesian films, workshops and discussions were organized in Islamic schools, universities, and organizations. These were set up to convince principals of Islamic schools and universities and heads of Islamic organizations that their students and members should become involved in film production and train to become skilled at it. ${ }^{18}$

After the resignation of President Soeharto, the developments of the past few years in conjunction with the climate of Reform led to a significant rise in activities which combined film with Islam. The number of professional production houses for Islamic films grew, and some Islamic organizations supported film production training courses for Muslims. Taking the bit between their teeth, different Islamic organizations participated in the organization of Islamic film screenings and discussions about audio-visual media. In addition to the cinema clubs of mainly Muhammadiyah universities, many newly established Islamic film communities embraced these activities enthusiastically. Among the new communities were M-Screen Indonesia (Muslim Screen Indonesia), Muslim Movie Education (MME), Fu:n Community (based on the Arabic word al funnuun, which means art), and the Salman Film-maker Club a film community connected to the Salman Mosque, which is part of the Technical University of Bandung. Such communities were composed mostly of young amateur and professional film-makers, Islamic students, and members of youth branches of established Islamic communities and organizations. A number, such as the Fu:n Community, also involved artists from the Jakarta Art Institute, Teater Kanvas, and Teater Bening, members of the non-governmental organization Mer-C, and Forum Lingkar Pena (FLP, Pen Circle Forum). The film crew affiliated to the Muhammadiyah production house PT Media Cipta Utama and some activists of other

\footnotetext{
17 'Pesantren jangan jauhi dunia kesenian dan film', Angkatan Bersenjata, 14-7-1993.

18 'Umat Islam harus ambil bagian ciptakan cerita sinetron', Angkatan Bersenjata, 24-9-1997; 'Seniman Muslim mesti kuasai audio visual', Republika, 12-7-1997. Cinema clubs at Muhammadiyah universities, for example, provided video cameras and other material to train students in film production (personal comunication with Chaerul Umam, in Jakarta October 2003).
} 
organizations also participated. ${ }^{19}$ The communities, led by young Muslim students and film-makers, showed a marked tendency to discuss motivations for the production of Islamic films and shape the rules and regulations required to govern this undertaking. Discussions waxed on subjects such as the way in which women should be depicted in Islamic films; the need to take breaks for prayer during the shooting of films; and whether or not Islamic films could be consumed by men and women in the same space at the same time.

To strengthen the Islamic film movement, a national association of Islamic film communities was founded in July 2003. The Morality Audio Visual Network (MAV-Net) consisted of representatives from six film communities and institutions: the Fu:n Community, M-Screen, Kammi, Rohis Mimazah, IKJ, MQTV Bandung, and a representative from the Pesantren Darunnajah. ${ }^{20}$ At the basis of this network lay the debates mentioned earlier about the need to resist the hegemony of foreign films and to strengthen the position of Islam in mainstream Indonesian audio-visual media. In the opinion of MAV-Net members, domestic 'Islamic' films and soaps, which after the fall of Soeharto were mainly screened on television during the Islamic fasting month of Ramadan, had nothing to do with Islam. They argued that access to 'real' Islamic films in Indonesia was restricted to pirated VCDs. These VCDs consisted of feature films, documentaries, and television series from Cairo, the United Kingdom, and Australia; but they also included films about Taliban training camps or Czech warfare, which were on sale and were considered Islamic films. ${ }^{21}$ In a manifesto MAV-Net underlined that it was extremely important to fight the film and television industry by producing films which were based on Islamic 'visual ethics'. ${ }^{22}$

19 Teater Kanvas is an Islamic theatre group founded by Zack Sorga, a graduate of the Jakarta Art Institute. The theatre group consists only of men. Teater Bening is a theatre group which consists of women only. Mer-C is an Islamic non-governmental organization which offers humanitarian aid. It was founded by Jose Rizal while he studied at the University of Indonesia. Forum Lingkar Pena is a group of predominantly young Islamic writers.

20 Also the Islamic boarding school Daarut Tauhid, AA Gym's Manejemen Qolbu Television and Manejemen Qolbu Cooperation, the Islamic women's magazine UMMI, Islamic youth from the Sunda Kelapa Mosque, and the magazine Aku Anak Saleh (I am a pious child) were mentioned as having joined the MAV-Net. Moreover, the MAV-Net worked together with such professionals in the field of audio-visual media as film directors Riri Riza, Chaerul Umam, Marissa Haque, Syaeful Wathon, Slamet Rahardjo Djarot, and Islamic artists such as Igo Ilham, Syamsudin Noor Moenadi, Rizal Basri, Moh. Ariansyah, Effendy Doyta, Zack Sorga, and others.

21 'Dakwah era baru dengan VCD', Majalah Suara Hidayatullah, January 2002, http:// hidayatullah.com/2002/01/muamalat.shtml (accessed 25-9-2002).

22 When I spoke to Agres Setiawan, co-founder of MAV-net, in March 2007, he said that his opinion had changed and that his view about the need to counter commercialism and transnationalism had become less radical. 
While the exact delineation of these Islamic visual ethics was still being debated, some main principles were set out in a pamphlet written by Ustaz (term of address for an Islamic teacher) Ahmed Sarwat from Pusat Konsultasi Syariah (Centre of Syariah (Islamic Law) Consultation). In this pamphlet, Ahmed writes that a film is only truly Islamic if Islam is the guideline in all the film mediation practices. He gives examples of the use of Islamic principles, from the production of an Islamic film (the producer, actors, and crew all have to be (devout) Muslims), to distribution (sponsors must produce halal goods), up to exhibition and consumption (the screening time should not be during hours of prayer, and cinemas should provide for a division between male and female audiences) (Sarwat 2003).

In the MAV-Net manifesto, the need for the production of films based on Islamic visual ethics was linked to an early theory of Third Cinema put forward by Teshome Gabriel. In 1985, Gabriel (1985:355-69) created a model which distinguished three phases of development in Third World national cinemas: the first phase of national cinemas in the Third World was characterized by the mimicry of Hollywood film productions; the second phase encompassed appropriations from traditional cultural products in both form and content (films about exotic traditional cultures); the third marked the engagement in a critical reassessment of traditional cultures, and the use of Third World filmmakers' own film languages, consisting of their original images, representations, and imaginations of society. This third phase often featured guerrilla sentiments and the deconstructions of conventional Eurocentric film themes and representations of First and Third Worlds. ${ }^{23}$ While Gabriel's model did not cover the huge amount of Indonesian films which combined elements of Hong Kong action films, Indian, and Latin American melodrama, plus all types of B-films from the US and elsewhere, the MAV-Net manifesto still used it to account for the need for Islamic films based on Islamic visual ethics. Islamic film was to constitute an authentic Indonesian and oppositional cinema, which would counter both the flow of films from the West and the allegedly corrupted commercial mainstream Indonesian cinema.

23 Sen argues that in Indonesian cinema under the presidency of Soekarno, Gabriel's third phase was represented by leftist film-makers who were opposed to imperialist Hollywood films. She states that when the New Order came to power, the third phase of cinema in Indonesia was erased (Sen 1994:46-7). Hence, the only movies surviving under the New Order were Gabriel's first-phase copies of Hollywood films, and second-phase films which showed exotic images of traditional Indonesian cultures. 
The founding of this oppositional cinema was not exclusively influenced by ideas about the position of Muslims in Indonesian domestic media and society. By 1999, discourses had emerged which extended ideas about the representation and position of Muslims to transnational media and world politics. Some Islamic scholars and television reviewers even argued that the distribution and exhibition of films and television series from the US and other imported entertainment in Indonesia was a carefully planned mission by the West to destroy Islamic religious principles. ${ }^{24}$ They believed that this mission was part of a strategy launched by Zionist Jews to control representations of the world. In these discourses, it was claimed that in the US, Jews controlled $80 \%$ of the Hollywood film industry and consequently strove to control and misrepresent the facts of world history, seizing the opportunity to undermine Islamic religious principles. ${ }^{25}$

Influenced by the same kinds of ideas, the communities affiliated to the MAV-Net network announced they were committed to countering the 'colonization of mainstream media by Zionists, imperialists, capitalists, and communists'. They saw themselves as part of an Islamic umat (religious community) which transcended the borders of Indonesia. Therefore, besides presenting an alternative cinema and defying the misleading representations of Islam on a national level, the goal of the film Islami movement was also to contribute to and increase the number of truthful representations of Islam worldwide. In forming a network which supported transnational Islamic film mediation practices, they strove to gradually convert the position of Western culture and ideologies, and their representations of history, in mainstream film mediation channels worldwide.

\section{FILM IN THE FRAMEWORK OF RAMADAN}

In the early years of Reform, the mechanism of screening films in a certain framework or relating them to a particular context persisted, in spite of the flow of discourses on reformation, and changes in conventional film mediation practices. The perception that there was a need to screen films as part of a specific occasion was highly

24 For a broader discussion of the emergence of these discourses in Indonesian society, see Schulte Nordholt 2008:170-1.

25 'Ali Sahab; Serial film TV meracuni generasi muda; ulama lebih mirip selebritis', Harian Terbit, 30-6-1999. For example, the series Melrose Place and Beverly Hills 90210 by 'Jewish producer' Aaron Spelling were seen to promote free sex and profoundly non-Islamic lifestyles. 
conspicuous in post-Soeharto debates about the commemoration of Hapsak. Although discussions raged about the discontinuation of the propaganda film $G 30 S / P K I$ as part of the media event, the screening of a film on 30 September was not questioned. ${ }^{26}$ There was also no controversy about the convention of relaying a film simultaneously on all television channels. ${ }^{27}$ In this section I will return briefly to the framework of Hapsak, after which I will further investigate the practice of screening films in the framework of another event during Reformasi. As the focal point of my argument, I will concentrate on 'Islamic' television programmes shown as part of the Islamic fasting month of Ramadan. I choose to link the Islamic fasting month with the practice of screening films in particular frameworks, both to stay within the 'frame' of the set up of Chapter 3, as well as in order to relate to Aulia Muhammad's analysis of the framing of Islam during Ramadan, which will be discussed in detail below. Special programming on television during Ramadan is not uniquely Indonesian. Also in, among other countries, Egypt, Malaysia, Syria, Turkey, and several other countries in the Middle East, television stations broadcast special programmes during Ramadan. ${ }^{28}$

On 1 October 1998, the commemoration of Hapsak was carried out in the conventional manner; the only omission was the screening of G30S/PKI as part of it. The official reason given for not screening the film was that it was damaged. However, it was also said that the screening of $G 30 S / P K I$ was discontinued because after twelve consecutive years of screening, television viewers must be bored watching it over and over again. ${ }^{29}$ There were also some who suggested that G30S/PKI was not consonant with the new era of Reform because the film was inclined to 'make a cult of a certain person' (pengkultusan seseorang), and to take the shape of a 'certain individ-

26 The continuation of the ceremony and the commemoration of Hapsak were also not questioned. However, in 2000 historian Taufik Abdullah criticized the sacredness of the Pancasila and its national day, because in the aftermath of the day being commemorated many people were killed and imprisoned and Pancasila was used to rule out all other ideologies, principles or beliefs (McGregor 2007:107).

27 Pengganti film G30-S/PKI mulai digarap', Merdeka, 4-9-1998; 'Bukan Sekedar Kenangan ditayangkan serentak 30 September 1998', Republika, 22-9-1998; 'TVRI tidak lagi tayangkan film G-30-S/PKI', Media Indonesia, 24-9-1998.

28 For a study of changes in television programming during Ramadan in Syria, see Christmann 1996 and Salamandra 1998. For an analysis of Ramadan programmes in Egypt, see Abu-Lughod 2002; Armbrust 2006.

29 'TVRI tak akan tayangkan film Pengkhianatan G 30 S/PKI', Pos Kota, 25-8-1998; 'Selamat tinggal Pengkhianatan G30 S PKI', Sinar Pagi, 25-8-1998; 'Film G-30 S/PKI dicabut; penggantinya tak singgung peran Soeharto', Merdeka, 26-8-1998. 
ual's personal monument' (monumen pribadi seseorang).$^{30}$ There was a general feeling that the viewers needed something new instead. Hence, on 29 and 30 September 1998, G30S/PKI was replaced by a television drama with the title Bukan sekadar kenangan (BSK, Not just a memory). It was emphasized that unlike G30S/PKI, BSK did not represent any personal monument, but was about common people.

In a new guise - above all, a love story - the intention of BSK was still to convey the traditional message: warning of the latent danger of communism. Moreover, BSK, just as G30S/PKI, was screened simultaneously on all television channels. Diverging from the former practice, however, it was agreed that G30S/PKI would not be replaced by one single film; a new film would be produced each year. ${ }^{31}$ This idea, however, never materialized. In subsequent years, and particularly under the presidency of Megawati Soekarnoputri (2001-2004), the Hapsak ceremony lost much of its credence. The Soekarno family had never accepted the official New Order version about the end of Soekarno's presidency, which paved the way for the legitimate succession of Soeharto, the version celebrated in the Hapsak ceremony. Since Megawati's presidency, the ceremony has not been broadcast on television in its entirety, but only in fragments inserted in daily news programmes.

As well as the initial endeavour to screen a film as part of the Hapsak media event, there was also an attempt to create new commemorative and other, more general events and relate these to specific film screenings. Either films were specifically produced and screened for certain events, or efforts were made to fit a film into an event. An example of the latter practice was apparent in the frequent changes of the title of the documentary Student movement to fit different film screenings. Under its original title, The army forced them to be violent, the documentary had been shown on campuses in Indonesia and at different film festivals abroad since 1998. However, at the instigation of LSF, its title was changed before it was certified to enter Indonesian cinemas. ${ }^{32}$ Notwithstanding Reformasi, it was still unacceptable to be too critical of the Indonesian army in films. Consequently, the title was changed to the neutral The student movement in Indonesia, by which name it was screened in the top-end cinemas of the 21 Group in August 2002. In November

30 'Film G-30-S/PKI diganti bukan sekadar kenangan', Harian Ekonomi Neraca, 24-9-1998; 'TVRI tidak lagi tayangkan film G-30-S/PKI', Media Indonesia, 24-9-1998.

31 'Film G-30 S/PKI dicabut; penggantinya tak singgung peran Soeharto', Merdeka, 26-81998; 'Pengganti Pengkhianatan G30 S PKI sepenuhnya fiktif, tanpa tokoh yang dikultuskan', Sinar Pagi, 27-9-1998; “Bukan Sekadar Kenangan” gantikan film "G-30-S/PKI”, Media Indonesia, 30-9-1998.

32 In 1992 the Badan Sensor Film had changed its name into Lembaga Sensor Film. 
of that year the documentary could again be seen in Indonesian cinemas. It was deemed perfectly suitable for the commemoration of the 'first Semanggi tragedy' (Tragedi Semanggi I), which had occurred on 13 November 1998. On that day, demonstrating students and a hapless bystander died after being fired upon by the Indonesian military near the Semanggi flyover in Jakarta; approximately 239 people were injured. On 13 November 2002, exactly four years after the incident, the documentary Student movement was screened in eight cinemas belonging to the 21 Group to commemorate the incident (Ati 2002). To suit the occasion of its re-release the title was first changed to Empat tahun Tragedi Semanggi I (Four years [after the] first Semanggi tragedy). ${ }^{33}$

The showing of films as part of a specific event or occasion is comparable to the broadcasting of 'Islamic' programmes on television during Ramadan. During the Islamic fasting month in Indonesia, the normal broadcasting schedule on television is interrupted. Television stations are suddenly flooded with Islamic programmes, and regular programmes which contain elements of violence, sex, and mysticism are rescheduled. As soon as Ramadan is over all programmes which may be construed to have ill effects on people return, and their Islamic counterparts disappear again. ${ }^{34}$ While the celebration of Ramadan on television during the New Order tended to be a rather modest affair, in post-Soeharto Indonesia it turned into booming business. In an interview, film director Ali Sahab in 2003 commented that during the launch of private television ten years earlier, Ramadan had not yet been commercialized. At that time Christmas was an even greater show than Ramadan. Sahab claimed that in due course the religious atmosphere disappeared from Ramadan television programmes. He commented that the fasting month had been turned into a spectacle in which only entertainment counted..$^{35}$

Signs of the development which was to transform Islam into a lucrative television business first began to emerge in 1999. Private television stations began to compete for a share of the advertisements in Ramadan programming, which increased by approximately $15 \%$ during the Islamic fasting month. ${ }^{36}$ The number of advertisements rose as some special products, among them sarung,

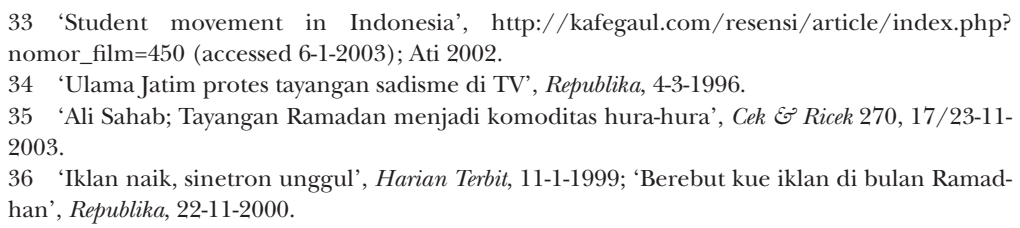


halal food products, and soap, were advertised only during Ramadan. In 2001 there was a particularly marked rise in the business and profits of Ramadan programming on television. In that year, several newspaper articles referred to the fierce competition between private television stations to grab a share of the advertisements, for which there were significant price increases in the Islamic fasting month. ${ }^{37}$ Although competition between the television stations increased, at that juncture there was hardly any change in the formulas of Ramadan programmes, either compared to what had been broadcast during the fasting month in previous years or to regular programming.

Implementing the laws of the market place and making a conscious attempt to copy tried and tested formulas, various television programmes were rerun during Ramadan. The questions in conventional quiz shows concentrated on matters of religion, and several soaps which revolved around the psychological or practical problems of people and the way in which religion could help to solve them, were launched. Nevertheless, despite a change in outward appearances (protagonists were dressed in Islamic clothes) and a change in prime time (to one hour before sunrise (sahur) and the breaking of the fast at sunset (maghrib)) quiz shows still focused on entertainment and soaps sold melodrama. Apart from these kinds of shows, Ramadan programmes were produced which were in line with the worldwide television trend of recent years. This trend had been marked by a mushrooming of infotainment and gossip programmes about the lives of artists and the 'rich and famous', clustered under the heading 'celebrities'. The only difference in the domestic infotainment shows produced during Ramadan was that female artists and presenters covered their heads and that some religious messages were inserted in the intervals. Often these Ramadan messages were delivered by an Islamic authority figure, for example a kyai or an ustaz, who had been invited for the occasion to be a guest star. ${ }^{38}$

In 2002, this propensity to include a religious authority figure began to be a feature in all types of Ramadan programmes. Standing out among them was the kyai and businessman Abdullah Gymnastiar, commonly known as AA Gym, who turned up almost everywhere. He featured in no less than nine television shows, which were divided

37 See, for example, 'Karena produsen berlomba2 pasang iklan; Ramadhan bawa berkah bagi TV swasta', Pos Kota, 4-11-2001; “'Perang” program TV menjelang sahur', Warta Kota, 10-112001; 'Program Ramadhan di televisi', Warta Kota, 10-11-2001; 'Ramai2 gaet pemirsa; Televisi bersaing tayangan Ramadhan', Warta Kota, 2001; 'Acara lama mendominasi program Ramadhan di TV', Kompas, 11-11-2001; 'Program TV Ramadhan mencari berkah dan rupiah', Media Indonesia, 18-11-2001.

38 'Kuis dan ceramah hiasi TV selama Ramadhan', Warta Kota, 22-10-2002. 
over five private television stations. ${ }^{39}$ AA Gym owned the television production company Manejemen Qolbu Televisi (MQTV, Management of the Heart Television) and produced and sold his own programmes. Other popular Islamic authority figures who appeared on national television that year were dai sejuta umat (Islamic preacher for the masses (lit. 'millions')) Zainuddin; Lutfiah Sungkar, a popular Betawi (native Jakartan) kyai, who had the gift of being a spellbinding speaker and who was also the leader of the political party Partai Bintang Reformasi (PBR, Star of the Reformation Party); and famous actor and dangdut singer Rhoma Irama. ${ }^{40}$ In 2003 the number of Ramadan programmes increased yet again. In their bid to compete with one another, the programmes varied from (sequels to) Islamic soaps, quiz shows to Ramadan programmes which were interspersed with elements of comedy, music, or wayang (literally 'shadow', traditional theatre with leather or wooden puppets). There were also live broadcasts of the preaching of Islamic leaders from mosques in different cities. In pride of place though was the increasing trend of featuring popular Islamic leaders in television programmes. AA Gym was by far the most popular. Advertisers of special Ramadan products fought with each other to fill the advertising slots around his programme ${ }^{41}$ but other such prominent Islamic leaders and personalities as Quraish Sihab and Arifin Ilham also appeared on various shows.

AA Gym's appearance on almost every television channel during Ramadan can be attributed to his credibility as an Islamic expert at that time, but the widespread media trend which focused on artists, the rich and famous, and popular people (the celebrity circuit) cannot be discounted either in seeking a reason for his success. ${ }^{42}$ Just as regular programming, which featured popular

39 On television station RCTI, AA Gym featured in Manajemen qulbu spesial Ramadhan; on SCTV in Membuka pintu langit, Gema Ramadhan, Sambut Ramadhan, and Gema takdir, on Indosiar in Kisah2 teladan (a children's programme); on Trans TV in Ceramah Ramadhan AA Gym, and on TPI, in Sentuhan qolbu Ramadhan. See 'Ramadhan di TV, AA Gym laris manis', Warta Kota, 1-112002; 'Serba AA Gym', Rakyat Merdeka, 5-11-2002.

40 'Ramadhan di layar televisi', Warta Kota, 9-11-2002.

41 'Bersaing program Ramadhan', Bisnis Indonesia, 26-10-2003; 'AA Gym di televisi; Dari subuh ketemu subuh', Cek Eo Ricek 270, 3/9-11-2003.

42 In 2006 AA Gym's popularity severely dropped following the news that he had taken a second wife. His popularity with women in particular, who formed the largest part of his fan base, decreased. The problem was not polygamy per se. Even though many Indonesian Islamic women do not support it, they acknowledge that the Islamic creed permits polygamy. However, the fact that AA Gym took a young and beautiful ex-Miss Indonesia model divorcee as his second wife, and not, for example, a hideous old widow, made people question his principles. In public opinion Gym's second marriage was merely based on lust. Despite the consent of his first wife and the validity in Islam to marry again, he was considered to have betrayed his first wife and family. This public view thoroughly damaged his credibility and image as a reputable person. As a result television contracts were pulled and the success of his business ventures declined with approximately $80 \%$. 
artists, comedians, and other celebrities, famous kyai were used to woo advertisers and attract as many viewers as possible. In 2003, an article in the newspaper Bisnis Indonesia mentioned that the fashion for featuring Islamic leaders on television during Ramadan had led to the birth of the category of 'kyai artists'. The article suggested that the 'camera face' of kyai artists was very important in reaching the masses, and not necessarily for the sake of dakwah; such personalities were also attractive to advertisers in the lucrative business of Ramadan programming. ${ }^{43}$

Others were less enthusiastic about the direction which was being taken. Several Islamic leaders and some television reviewers criticized what they regarded as the commercialization of Islam. In 2004, the Indonesian Ulama Council, which had tried to steer the contents of Ramadan programmes since 2001 by handing out a yearly award for 'Best National Ramadan Television Programme', remonstrated about what it saw as the trend in which Islamic television during Ramadan was being 'degraded to mere entertainment'. ${ }^{44}$ Noted television reviewers, among them Akhmod Seku and Indra Tranggono, joined the chorus of disapproval of the use of Islam in the Ramadan programmes, castigating these programmes as nothing more than a 'formality'. Their criticism was based on the argument that these programmes were devoid of any real substance and for that very reason could be seen as examples of Umar Kayam's notion of performing arts 'in the framework of' ${ }^{45}$ Aulia Muhammad wrote that he experienced a sense of vacuity as he watched television during Ramadan. In his article, he connected this sense of emptiness to Henry Lefebvre's analysis of meaninglessness which he had read about in Dick Hebdige's book (1979:117) Subculture; The meaning of style. Aulia criticized the Ramadan programmes for their blatant focus on the outward appearance of famous artists and the depiction of 'seasonal repentance', or, as he expressed it, 'the selling of tears'. Each year during Ramadan celebrities donned a recognizably Muslim costume and, in an orgy of self-abasement, burst into tears on entertainment shows, begging forgiveness for the scandals in which they had been involved. Aulia's objections were based on Baudrillard's conception $(1998: 110,193)$ of the loss of the intrinsic meaning of seasonal changes and differentiations in 'consumer society' - a

43 'Camera face perlu jadi pertimbangan', Bisnis Indonesia, 26-10-2003.

44 Tayangan program Ramadan, diamati ketat', Kedaulatan Rakyat, 4-11-2004.

45 See also interviews with Veven Wardhana in Kusumaputra 2002, and remarks by film director Ali Sahab in 'Ali Sahab; Tayangan Ramadan menjadi komoditas hura-hura', Cek $\mathcal{E}$ Ricek 270, 17/23-11-2003. 
society in which consumption forms the total be-all and end-all of everyday life. In other words: the celebrities during Ramadan merely '[spoke] with their clothes'. The clothes reflected the seasonally dictated life- styles and temporary identity assumed during the fasting month. In Aulia's opinion, celebrities dressed up and acted the roles required by the sentiment evoked by Ramadan because they believed that the television audiences expected it of them. Aulia argued that the annual circus surrounding Ramadan reflected 'the real post-modern face of television as a sea of illusion, an imaginary world, and hyper-reality, which should not be believed' (Muhammad 2004). In this context, the previous use of a framework during the New Order to direct the reading of a film was discarded, at least in part. Rather than directing the meaning or reading of a film, the framework itself had now become the focal point.

\section{CONCLUSION}

After the stepping down of President Soeharto, new post-colonial discourses and imaginations of society were reflected in both the discourse practices of text production and in the conventions of framing films at the level of text consumption. The new-found freedom of expression offered by the socio-political situation of Reform induced several tentative, incomplete, and contradictory changes in the shifting discursive practices of the media (Fairclough 1995:52).

The first tentative and incomplete changes and some continuity could be discerned in the modes of engagement in post-Soeharto documentaries. Such documentaries as Mass grave and Student movement substituted new narrations for old images, and new images for old narrations. Nevertheless, as well as most of the documentaries produced in the first few years after the fall of Soeharto, they used the same modes of engagement of New Order representations of history and society in film. In their narratives, most documentaries followed either the New Order/USAI development film formulas, or what may be designated the Usmar Ismail mode of heroism. The difference in the post-Soeharto documentaries was that the viewpoint was anti-New Order. A majority of the documentaries focused on newly created heroes or on victims of Soeharto's rule, but there was also a change in the discourse. The heroes of the post-Soeharto documentaries were not authority figures, but victims and common people. 
The changes in discourse practices relating to the continuation of the convention to screen films in the framework of a certain event were contradictory. In the context of the screening of 'Islamic' television films and programmes during Ramadan, these contradictions were to some extent related to discourses of the film Islami movement founded in 2003. Paradoxically, at the same time when an association of film Islami groups was founded to promote Islamic visual ethics for film, Indonesian commercial television turned the screening of soaps and programmes containing features of Islam into a booming business. A survey of the discourses about media representations of Islam during Ramadan shows that in contrast to the idea of Islamic visual ethics, which inserted Islam into all aspects of film mediation practices, the television shows during Ramadan mostly availed themselves of their outer shell.

The commercialization of Ramadan programmes is part of a broader trend of commodification of religion in the sphere of entertainment, in Indonesia and elsewhere in the world. ${ }^{46}$ Not only Islam is affected by this trend of commercialization; other religions, too, are progressively turned into marketable products in mass media and as part of lifestyle markers. ${ }^{47}$ The commodification of religion is seen as constituting part of a trend of neo-liberal capitalism. In Indonesia, commercial Islam started with the rise of affluent middle classes following the economic growth during the New Order in the 1990s. Ariel Heryanto has described the way in which the formation of a new middle-class identity and the analogous establishment of a capitalist domination gave a boost to the advance of new Muslim elites. In his analysis of the 'new' Muslims, Heryanto shows the development of an increasing amalgamation of religion and politics with consumptive lifestyles. ${ }^{48}$ Various scholars have argued that in the past decade, Islam in Indonesia has turned into a commodity ${ }^{49}$ Islam sells well in lifestyle products, such as clothes, food, health services, travel and tourism, as well as across a broad range of media, such as books, magazines, music, radio and television talk

46 For example, Lila Abu-Lughod and Walter Armbrust have described similar developments in Egypt. Abu-Lughod (2002:127) analysed the rise in production and popularity of big-budget religious and religious-historical series on Egyptian television during Ramadan at the end of the 1990s; also in the context of Ramadan on television, Armbrust (2006) researched the blurring of boundaries between religious observances and entertainment.

47 For examples of the commodification of Christianity in the sphere of entertainment in the United States, see Moore 1994; Forbes and Mahan 2000; for examples from Ghana, see Meyer 2004, 2007.

48 Heryanto 1999:164, 173-6. In his study on Islamic consumption in Malaysia, Fischer (2009) shows that the promotion of Islamic consumption by the state has produced an alternative form of Islamic neo-liberal capitalism.

49 Fealy 2008; Hasan 2009; Hoesterey 2008; Nef-Saluz 2007. 
shows, soaps, religious text messages on mobile phones, and films. Some see the 'consumption of Islam' as a positive development, in that it brings new religious meaning into the lives of Muslims, and further supports a society based on religious principles (Fealy 2008:16). To others, however, the commercialization of Islam has meant an erosion of its religious essence. As Islamic scholar Ahmad Syafii Maarif argues, to many people it seems to be more about 'looking Islamic than being Islamic' (Fealy 2008:35-7, italics in original). In Islamic discourses, proponents of the latter argument, such as Aulia Muhammad and the film Islami groups, perceived the programming of Islamic soaps and other series in the framework of Ramadan as nothing more than a commodity at the disposal of the television industry. In this context the spirit of the Ramadan soaps and programmes was stifled by the framework in which they were screened.

Also on other occasions, the use of frameworks can be connected to commercial motives. Films were often screened in the framework of certain events as a ploy to sell more tickets. Conceivably, the change of the title of Tino Saroengallo's documentary Student movement to fit the commemoration of the 'first Semanggi tragedy' was based on commercial premises too. By re-releasing the documentary under another title, it was anticipated it would attract more viewers. In the previous chapter I have argued that as an instrument employed by the New Order, one important function of a framework was to direct the reading of film and television productions. In the post-Soeharto mediascape, however, frameworks should rather be seen as tools to make these productions more saleable.

The shallowness, the temporal identities, and the 'hyper' reality of the Ramadan programmes and soaps were all decidedly antithetical to discourses which urged the need for truthful self-representations and Islamic visual ethics. The lack of authenticity spawned by this backdoor commercialism was also in contrast to the emphasis on 'getting history straight', and the stated bid for 'true' and 'real' representations of history and society. Moreover, when the Ramadan programmes and the post-Soeharto documentaries are compared, the emphasis on the allure of celebrities in the former stands out starkly in contrast to the focus on common people in the majority of post-Soeharto documentaries.

The focus on both reality and common people as well as celebrities - both secular and religious - is not limited to Indonesia; this too is a phenomenon that can be observed in global media trends. In the case of reality and the common people, in post-Soeharto Indonesia there were two readily identifiable shifts: from an emphasis on the voice of authority to the 'voice of the voiceless' 
and to ordinary people in the production of post-Soeharto documentaries; and a marked tendency on television to broadcast programmes featuring the man in the street. The emphasis on factual reality and common people began as part of the discourses which questioned New Order historiography and its imposition on society. In the first few years of Reform, numerous talk-shows on television addressed these issues, and over time, people tired of these shows. Corresponding to transnational trends in television, the initially overriding truth and reality in these rather serious talk-shows was replaced by the production of all types of light-entertainment reality shows featuring common people. In the same vein, the focus on celebrities in Ramadan programmes was part of a worldwide trend on television, which showed popular infotainment and gossip programmes about the rich and famous. Hence, while television was crammed with reality shows featuring ordinary people, it was also flooded with celebrities. The emphasis on celebrities in programmes broadcast during the fasting month even resulted in the birth of celebrity kyai. This invention of the celebrity kyai corresponds with another global television trend: a new religious format evolving around charismatic media personalities. ${ }^{50}$

In 2004, 'Islamic' soaps and series managed to escape the framework of Ramadan, and were subsequently screened outside the confines of the fasting month. However, they were still made for commercial reasons and they still contained prefabricated televised representations of Islam. The focal point of these soaps was that they were based on true stories, spiced up with elements of mystery - such as supernatural occurrences - and scenes in which people indulged in paroxysms of tearful repentance. An important component was the major role assigned to heroes in the guise of Islamic authority figures, kyai celebrities, or sometimes personalities who combined these two traits. In Part Three I will look more closely at reality shows, true stories, and representations of Islam outside of the framework of Ramadan.

50 For similar developments in Egypt, see Bayat 2002; in Ghana, see De Witte 2003; in Israel, see Lehman and Siebzehner 2006; in Mali, see Schulz 2006; in Turkey, see Öncü 2006. 